\title{
Remembering Derrida
}

\author{
Robert J. Antonio
}

French President Jacques Chirac announced Jacques Derrida's death, stating "With him, France has given the world one of its greatest contemporary philosophers, one of the major figures of intellectual life of our time." Derrida was the leading figure of the literary thread of poststructuralist and postmodernist thought. His approach"deconstruction"- has inspired scholars across disciplines in literary study, cultural theory, and postmodernist analysis. Legal scholars applied Derrida's ideas in "critical legal" studies, and architects deployed them in their "deconstructivist" phase. Derrida criticized Eurocentric thought, and supported the entry of women, people of color, gays and lesbians, and other marginalized groups into mainstream academic, political, and cultural life. His ideas about these matters contributed significantly to the rise and development of the late 20th century "cultural left." Critics sometimes deride Derrida as a "celebrity philosopher." He has had impact on popular culture. Cultural writers and media critics employ his terms in mass media commentaries, he and his ideas are often invoked in the US "culture wars" over "multiculturalism" and "political correctness," and references to him and his ideas appear in popular culture (e.g., the movie Deconstructing Harry, Derrida was featured in a song by the Welsh post-punk band, Scritti Politti, and in an Egyptian folk song, and a movie documentary about him includes twenty-nine musical tracks ostensibly inspired by him).

Derrida was born and raised in Algeria, then a French colony. A Jewish child living under the collaborationist Vichy government during World War II, he was dismissed from school as a result of the regime's anti-Semitic laws. He learned early what it meant to be "the other." After the war, he studied at the elite École Normale Supérieure, where he met and established a long acquaintanceship with the structuralist Marxist Louis Althusser. Derrida was influenced much more by Heidegger and Nietzsche than by Marx. He also engaged Hegel, Husserl, and other Continental and Classical philosophers, structuralist theorists (Claude Lévi Strauss, Roland Bathes, and Althusser), and major modernist writers. Derrida taught philosophy in Paris for more than twenty years, and later taught at Johns Hopkins, Yale, and University of California at Irvine. He was a prolific writer, dynamic lecturer, and charismatic intellectual.

Following in the tracks of Nietzsche, Wittgenstein, and Heidegger, Derrida stressed the role of language to engage critically western philosophy's problematic concepts of reason and truth; however, he added some new twists. Focusing more on developing a critical theory of reading than framing a comprehensive philosophical vision, Derrida argued that texts neither have fixed meanings nor mirror an author's singular vision. He held that fluid, contingent, plural meanings are obscured or suppressed by socially-constructed binary oppositions (e.g., good-evil, man-women, rational-nonrational, heterosexual-homosexual). He aimed to overturn them by challenging the privileged term and allowing fluid borders, contradictions, and multiplicity to become visible. Although he refused to provide a fixed definition, "deconstruction" refers to his overall effort or various strategies to reveal the plural, conflictive facets of culture embedded in texts. Derrida urged readers to question presuppositions of texts and to engage what is blurred, marginalized, or left out. He resisted linguistic conventions, which he believed impose enormous social constraint and reproduce relations of domination and subordination.

Commentaries about Derrida's passing appeared worldwide. It is hard to imagine the death of any academic intellectual drawing this much attention and generating such heated responses. Even USA Today, CNN, Fox News, and many local news outlets reported about his death, wide impact, and controversial status. More highbrow outlets ran substantial essays about his legacy and, sometimes, multiple, conflicting pieces about it. Le Monde had a ten page 
section about him. A German outlet ran comments by Jürgen Habermas, Axel Honneth, and Judith Butler. The Times of London published a detailed article on Derrida's life that addressed, in a balanced way, critics' charges that his work is "nihilist and irresponsible" and related battles over this view (e.g., the furor over his receiving an honorary degree from Cambridge). The paper also published critical pieces about his ideas with satirical titles ("This May Mean Something?" and "Is Derrida Dead?"). Other articles, on unrelated topics, made comic, passing references to his ideas. The New York Times also ran three divergent commentaries about him, and he was mentioned briefly in other pieces. Letters contesting his legacy have abounded, portraying him as the "world's greatest philosopher" and "creative genius" or as a "charlatan" and "axeman of Western philosophy." In The Chronicle of Higher Education, combative e-mails included dueling poetic dirges, personal invectives, and vituperative exchanges, drawing on everything from Nazism to the politics of John Kerry, George W. Bush, Ann Coulter, Bill O'Reilly, and "Swiftboat Veterans For Truth." The polarized views echo the 1990s "science wars" over postmodernism, which cut across disciplines and culminated in the "Sokal Affair" (i.e., the widely publicized debate over a natural scientist fooling the editors and publishing a cleverly crafted, totally bogus essay on postmodern science in the cultural studies journal, Social Text). This battle dramatized a most contested facet of Derrida's legacy expressed centrally in the contentious fight over how he should be remembered: Did he facilitate recovery of elided meanings, which have instrumental, normative, or aesthetic value, or did he erase the standards by which they are deemed valid, good, or beautiful and, thus, undercut the critical judgment, delimited focus, and sustained effort that substantial cultural achievements and even effective daily life require? Did he enrich our understanding of reality, or dissolve it?

The US cultural-right intelligentsia portray Derrida as a central figure in a morally and intellectually bankrupt, liberal left (i.e., a hegemonic "new class" ensconced in academe and other cultural institutions, widely influential in Hollywood and the media, and the source of noxious "political correctness"). In The Closing of the American Mind, the neoconservative broadside about the supposed sorry state of American higher education, Allan Bloom charged that Parisian emigres littérateurs led the US left to abandon Marx for Nietzsche and Heidegger and that deconstruction fueled America's worst cultural inclinations. Bloom saw Derridian currents epitomizing the nihilism and relativism that he held infect the humanities and social sciences, suffuse popular culture, threaten to destroy American cultural standards and moral fibre and, thus, make the nation vulnerable to protofascist currents. The Wall Street Journal's piece on Derrida's passing_"'The Meaninglessness of Meaning"—is in tune with Bloom's earlier charges.

Left-wing critics express parallel criticism. In 1987, the year that Bloom's book appeared, Derrida's recently deceased friend, Yale colleague, and fellow deconstructionist, Paul de Man, was exposed for having written articles, when he was a young man, in a Belgian newspaper that collaborated with the Nazis. There was no trace of rightwing or racist ideas in de Man's later work, but Derrida's critics used the discovery to attack deconstruction. Victor Farías' widely-read portrayal of Heidegger's collaboration with the Nazis appeared the same year. The public furor over de Man and Heidegger cast a shadow on Derrida, but few of his critics made any effort to elaborate the connections between the two affairs and deconstruction. Derridians countercharged that the critics had not read Derrida's work or other deconstructionist texts. The critical attacks generated more heat than light. A few years later, left-leaning Richard Wolin charged that Derrida read Heidegger superficially, without sufficient attention to historical and political context, and that deconstruction opens the door to reactionary currents. Also, a legal fight ensued over Wolin's attempt to publish a Derrida interview (for which Wolin had secured permission) in a collection on the Heidegger controversy. This public battle drew media attention, and reached the pages of The New York Review of Books.

In the 1980s, other critics, such as Perry Anderson, Luc Ferry and Alain Renaut, and Peter Dews, criticized Derrida's views of language, subjectivity, and history, connected them to the broader postmodernist theory, and held that they contribute to the erosion of liberal-left political agency and to a cultural climate favorable to reactionary politics. Wolin's recent Seduction of Unreason locates Derrida among thinkers influenced by Nietzsche and Heidegger, and alleges that their radical critiques of Enlightenment rationality undermine the presuppositions of liberal democracy and feed radical-right tendencies. Derridians hold that such criticism is based on erroneous views of deconstruction. They also point to Derrida's support for dissidents in the former communist Czechoslovakia, opposition to South African apartheid, and advocacy for French immigrants and international human rights. Some scholars hold that Derrida made an "ethico-political" turn in later life (i.e., manifested in his work on Marx, assertions that justice cannot be deconstructed, opposition to the Iraq War, and other left-leaning gestures), but other supporters insist that progressive themes were always present in his thought and inhere in deconstruction. Even some sharp critics of 
postmodernism acknowledge progressive facets of Derrida's political legacy. For example, Richard Rorty's Achieving Our Country decries the cultural left's lack of a constructive vision of progressive democracy, but concedes that they have contributed substantially to delegitimation of sadistic practices that heap stigma and humiliation on culturally marginalized groups. Terry Eagleton railed against Derridian currents in After Theory. However, his Guardian article about Derrida's passing praised the "stunning originality and intricacy" of his work and memorialized him as an important carrier of the "heritage of May ' 68 " and staunch leftist who helped open the postwar left to the marginal and voiceless.

A certain style of "Derridian" writing has drawn especially hostile reactions, and is a prime source of the dismissive views of his legacy. Although clear in critics' minds, the relation of this work to Derrida's corpus is debatable. Derrida's impact on postmodern discourse is hard to determine with any precision, because his ideas are often fused haphazardly with those of Foucualt, Lyotard, Baudrillard, Gramsci and others. Many writers who use Derrida's terms have not read his work closely, or at all. However, the widely criticized style of "Derridian" work simulates digging deeply while skimming over the surface of texts, ignoring their historical contexts, and reading them very unsympathetically, with little effort to play the role of the other or exercise self-criticism. These "Derridians" repeat erroneous conventions about "modern theorists," pose uninformed, blanket criticism of science per se, and employ references to theorists and concepts to consecrate their normative claims. They use "Derridean" buzzwords in defense of identity politics, hardening binary thinking and forging Schmittian "friend-enemy" dichotomies. Rather than close readings and multiple meanings, their moralizing rhetoric, obscured by fancy literary maneuvers and self-indulgent jargon, results in predictable caricatures and superficially clever, nonsensical, bad writing. Their extreme textualism, or radical "constructivism," manifests a self-referential subjectivism and elision of the body and object world that Nietzsche charged plagues classical western rationalism. Valorizing such work as "Theory," these "Derridians" uphold the very Platonism they claim to escape.

Thinkers embracing the "critical" side of the Marxist tradition have long held that Marx did not advocate the crude "base-superstructure" model attributed to him by his "orthodox" followers and dismissive critics. Engels reported that Marx asserted, commenting on his younger followers' mechanistic materialism, that: "All I know is that I am not a Marxist." Derrida was too kind hearted to berate his misguided followers, but much of their work runs counter to his views and intent. Like Marx's corpus, however, his texts provide bases for the problematic work conducted in his name. Derrida's intentionally obscure, prolix style, unwillingness to define key terms, and employment of neologisms and puns open his texts to misreading and to appropriation by weak, irresponsible thinkers. He gave such strong priority to language and suggested such an open horizon of meaning that he left ambiguous the relations between texts and their external contexts. His vocabulary does not give voice to the obdurate nature of the external world (i.e., that objects, including our own bodies, resist, regulate, or extend beyond representation), how we pragmatically test linguistic categories (e.g., touching an object said to be hot), and how the range and contingency of meaning is regulated by different types of external contexts and pragmatic tests (e.g., "normative" or "aesthetic" views of a literary text versus "factual" instructions about an instrumental routine [how to exit a building]). Derrida's break with the communication model and provision of privileged status to the written word turns attention away from the embodied side of language, interactive meaning construction, and efforts to reach understandings through mutually corrective gestures. His one-sided emphasis on contradictory, multiple meanings favors fragmented views of subjectivity and history and valorizes difference decisively over consensus, solidarity, and cooperation. Derrida does not escape the western "philosophy of the subject."

While I was completing the last few paragraphs of this commentary, a cultural studies student from our American Studies Program visited my office to talk about taking my survey course in Modern Social Theory. We discussed his tentative dissertation topic concerning ethnic and racial representations in professional wrestling. Although precisely the type of topic ridiculed in the dismissive critiques of Derrida and postmodernism, this student's animated discussion, replete with Derridian sensibilities, raised serious questions and posed innovative ideas, which made me reflect on a facet of popular culture in new ways. He explained that he wanted to study modern theory to expand his historical and sociological knowledge and to provide a stronger foundation for his work on culture and identity. He reminded me of other students who I have worked with, during the last two decades, who had similar cultural studies backgrounds and who have related to me how their engagement with Derridian or postmodernist currents opened them to new perspectives, led them to investigate topics that they ignored previously, caused them to think critically about their views and claims, and inspired them to engage in fresh projects. At times, I have observed traces of the problematic facets of the Derridian legacy in their work. However, they have, on the whole, expressed a moral 
earnestness, openness to alternative perspectives, and intellectual seriousness, energy, and creativity that is never addressed by the dismissive critics of Derrida and postmodernism. These students manifest the side of Derrida's legacy articulated in the celebratory eulogies.

Christopher Norris described deconstruction as “rigorous demystification.” Derrida's effort to make problematic taken-for-granted cultural objects and encourage critical inquiry into their contradictory, hidden sides likely derives from his engagement of Nietzschean ideas. Nietzsche held that reified linguistic categories_-"conceptual mummies"foster mechanistic responses to stimuli. He saw this unreflective manner to inhere in classical western philosophy's transcendental or fixed idea of Truth, which takes the form of banal conventionalism (e.g., rigid moralism, racial stereotypes) and compulsive conformity in the broader culture. Decrying "indecent haste," Nietzsche called for a cultural education that teaches us to resist immediate responses to stimuli, to be slow, mistrustful, and critical in our linguistic practices, and to see what is obscured. In the preface to Daybreak, he urges us to "read well, that is to read slowly, deeply, looking cautiously before and aft, with reservations, with doors left open with delicate eyes and fingers...” Albeit with less eloquence and philosophical boldness, Derrida calls for similar reflexivity. This rich vein in his thought carried into wider postmodern discourses, and is a source of my students' and other Derridians' claims about new inspiration, growth, and insight.

Deconstruction can serve divergent political ends. However, Derrida's left-leaning version can still be used effectively against arrogant scientism, which obscures normative ends and shuts down debate over them. It also might be turned against those "friend-enemy" and "good versus evil" binaries, suffusing populist moral rhetoric, identity politics, and political advertising. Deconstructionist critics of imperial geopolitics might ask; "What is suppressed or obscured when President Bush declares that the US is fighting for 'freedom' and 'democracy' in Iraq, when he opposes the idea of 'civilized world' against the 'axis of evil,' or when speaks of 'the war against terror?”' However, some of Derrida's later moves (e.g., going back to Marx or asserting that justice cannot be deconstructed) imply that he was aware that something vital was left out of his approach. Deconstructing Derrida requires coming to terms with the absence of a vocabulary valorizing the reconstructive tasks of forging solidarities, cooperative networks, or planning regimes. We need historically and sociologically determinate, yet comprehensive, social theories that can pose possible new regimes capable of cultivating environmental responsibility, democratic redistribution and participation, and, most importantly, sustainable alternatives to nearly globally hegemonic neoliberalism. This task requires articulation of forceful, focused, and somewhat singular normative arguments (i.e., which distinguish assertively good from bad ends) and arguments that are finely attuned to historical and sociological conditions that may favor or block prospective policy aims. We must go beyond Derrida, but remembering deconstruction and deploying its critical sensibilities in a supplementary way might help avert some of the terrible blinders and bloody mistakes of the last reconstructive era.

Postmodern ideas gained impetus when the post-World War II era was winding down in the 1970s; the long boom ended, the New Left collapsed, Marxist regimes and wars of national liberation were spent, welfare states suffered fiscal and legitimacy crises, and the cultural right and neoliberalism began their triumphal march. In the 1980 s, postmodernism gained even more momentum with the development of nascent "fast capitalism" (i.e., new forms of business organization, communication and information technology, media, entertainment, and finance) and of a vibrant politics of recognition (e.g., race, gender, ethnicity, sexuality) that helped animate even stronger postmodern currents. By the early 1990s, the collapse of the Soviet Bloc ended postwar geopolitics, while the first Gulf War and talk of a New World Order suggested an ominous new direction. Postmodern sensibilities expressed contradictory tendencies: liberating release from rigid, limited, repressive facets of Cold War culture and depressing acquiescence to plutocracy, hardened class-lines, spatial apartheid, culture wars, violent neotribalism, and extreme sound-bite politics. Late eighties and earlier nineties endings discourses — the "end of alternatives," "end of left and right," "end of politics," and "end of history" - expressed poignantly the exhaustion of postwar visions of progressive modernization (centrist and left) and a political and cultural twilight time of conflicting openings and closures. The events of $9 / 11$ added more complexities. Derrida's contradictory, contested legacy is entwined with this historical conjuncture's counterflows (i.e., its dispersed meanings, differences, fragmentation, contingency, presentism, textualism). How then to remember him? Nietzsche said that: "One is Fruitful only at the cost of being rich in contradictions..." and that this wealth provides "antennae for all types of people." Derrida's multiplicity mirrors postmodern times. Adieu Derrida! 